\title{
HUBUNGAN PENGETAHUAN DAN DUKUNGAN KELUARGA TENTANG ASI EKSKLUSIF DENGAN PEMBERIAN ASI EKSKLUSIF DI WILAYAH KERJA PUSKESMAS SEKARAN KOTA SEMARANG
}

\author{
THE CORRELATION OF KNOWLEDGE AND FAMILY SUPPORT ABOUT EXCLUSIVE \\ BREASTFEEDING WITH EXCLUSIVE BREASTFEEDING ASSIGNMENT \\ IN SEKARAN COMMUNITY HEALTH CENTER OF SEMARANG
}

\author{
$\underline{\text { Dewi Elliana }^{1)} \text { Titik Kurniawati }^{2)} \text { Roifatur Roekhanah }^{3)}}$ \\ 1)2)3) Akbid Abdi Husada Semarang \\ E-mail: elliana_dewi@yahoo.com
}

\begin{abstract}
ABSTRAK
Data Riset Kesehatan Dasar (Riskesdas) 2013 menunjukan pemberian ASI di Indonesia saat ini masih memprihatinkan. Prosentase bayi yang menyusu eksklusif sampai dengan 6 bulan hanya 30,2\%. Di Jawa Tengah cakupan pemberian ASI eksklusif tahun 2012 hanya 25,6\%, menurun dibandingkan tahun 2011 yaitu 45,18\%. Tujuan untuk mengetahui hubungan pengetahuan dan dukungan keluarga tentang ASI eksklusif dengan pemberian ASI eksklusif di wilayah kerja Puskesmas Sekaran Kecamatan Gunungpati Kota Semarang. Penelitian ini termasuk penelitian bidang kebidanan dalam melaksanakan pelayanan kebidanan pada komunitas dengan pendekatan retrospektif. Populasi dalam penelitian ini adalah ibu yang mempunyai bayi usia 7-11 bulan yang berjumlah 47 responden dan sampel yang diambil berjumalah 47 responden dengan teknik sampling jenuh. Tingkat pengetahuan ibu tentang ASI eksklusif termasuk kategori cukup (51.1\%). Dukungan keluarga dalam pemberian ASI eksklusif yang mendukung (29.8\%). Pemberian ASI eksklusif sebanyak (8.5\%). Hasil analisis bivariat pengetahuan tentang ASI eksklusif sebesar 6,221 sehingga p value sebesar $0.016(p=0.016<0.05)$ maka ada hubungan yang bermakna antara pengetahuan dengan pemberian ASI eksklusif diwilayah kerja Puskesmas Sekaran Kecamatan Gunungpati Kota Semarang. Sedangkan dukungan keluarga dengan $p$ value sebesar 0.073 ( $p=0.073>0.05)$ maka tidak ada hubungan yang bermakna antara dukungan keluarga dengan pemberian ASI eksklusif diwilayah kerja Puskesmas Sekaran Kecamatan Gunungpati Kota Semarang. Ada hubungan antara pengetahuan tentang ASI eksklusif dengan Pemberian ASI eksklusif di wilayah kerja Puskesmas Sekaran Kecamatan Gunungpati Kota Semarang, Tidak Ada hubungan antara dukungan keluarga ibu tentang ASI eksklusif dengan Pemberian ASI eksklusif di wilayah kerja Puskesmas Sekaran Kecamatan Gunungpati Kota Semarang.
\end{abstract}

Kata kunci : : Pengetahuan, dukungan keluarga, pemberian ASI eksklusif

\section{ABSTRACT}

Basic Health Research Data (Riskesdas) 2013 shows breastfeeding in Indonesia is currently still apprehensive. The percentage of exclusively breastfed infants up to 6 months was only 30.2\%. In Central Java, exclusive breastfeeding coverage in 2012 was only 25.6\%, down from 45.18\% in 2011. Objective: to know the relationship of knowledge and family support about exclusive breastfeeding with exclusive breastfeeding in work area of Sekaran Community Health Care Of Semarang City. This study included obstetric research in performing midwifery services in communities with a retrospective approach. The population in this study were mothers who had babies aged 7-11 months, amounting to 47 respondents and the sample taken numbered 47 respondents with saturated sampling technique. Maternal level of knowledge on exclusive breastfeeding included adequate category (51.1\%). Family support in exclusive breastfeeding support (29.8\%). Exclusive breastfeeding as much as (8.5\%). The result of bivariate analysis of knowledge about exclusive breastfeeding is 6,221 so that $p$ value is $0.016(p=0.016<0.05)$ then there is a significant relationship between knowledge and exclusive breast feeding in the work area in Sekaran Community Health Care Of Semarang. While the support of family with $p$ value of $0.073(p=0.073>0.05)$ then there is no significant relationship between family support and exclusive breastfeeding in the work area in Sekaran Community Health Care Of Semarang. There is a relationship between knowledge about exclusive breastfeeding and exclusive breastfeeding in the work in Sekaran Community Health Care Of Semarang, No relation between mother's family support about exclusive breastfeeding and exclusive breastfeeding in work area in Sekaran Community Health Care Of Semarang.

Keywords: Knowledge, family support, exclusive breastfeeding 


\section{PENDAHULUAN}

Angka kematian Bayi (AKB) merupakan jumlah kematian per 1000 kelahiran hidup dalam kurun waktu satu tahun. AKB menggambarkan tingkat permasalahan kesehatan masyarakat yang berkaitan dengan faktor penyebab kematian bayi, tingkat pelayanan antenatal, status gizi ibu hamil, tingkat keberhasilan program KIA dan KB serta kondisi lingkungan dan sosial ekonomi. Apabila AKB disuatu wilayah tinggi, berarti status kesehatan di wilayah tersebut rendah (Kemenkes Jateng, 2012).

AKB di Provinsi Jawa Tengah tahun 2012 sebesar 10,75 / 1000 kelahiran hidup, meningkat bila dibandingkan tahun 2011 sebesar 10,34 /1000 kelahiran hidup (Kemenkes Jateng, 2012).

Berdasarkan Peraturan Pemerintah Nomor 33 pasal 2 Tahun 2012 Tentang ASI Eksklusif yaitu menjamin pemenuhan hak bayi untuk mendapatkan ASI eksklusif sejak dilahirkan sampai dengan berusia 6 (enam) bulan dengan memperhatikan pertumbuhan dan perkembangannya, memberikan perlindungan kepada ibu dalam memberikan ASI eksklusif kepada bayinya dan meningkatkan peran dan dukungan keluarga, masyarakat, pemerintah daerah dan pemerintah terhadap ASI eksklusif (Kemenkes RI, 2012).

Meskipun menyusui dan ASI sangat bermanfaat, namun belum terlaksana sebelumnya. Diperkirakan $85 \%$ ibu - ibu didunia tidak memberikan ASI secara optimal. Tahun 2010 cakupan ASI eksklusif di India saja sudah mencapai $46 \%$, di Philippines 34\%, di Vietnam 27\% dan di Myanmar 24\% (Yuliarti, 2010).

Data Riset Kesehatan Dasar (Riskesdas) 2013 menunjukan pemberian ASI di Indonesia saat ini masih memprihatinkan. Prosentase bayi yang menyusu eksklusif sampai dengan 6 bulan hanya 30,2\%. Di Jawa Tengah cakupan pemberian ASI eksklusif tahun 2012 hanya $25,6 \%$, menurun dibandingkan tahun 2011 yaitu $45,18 \%$ (Kemenkes Jateng, 2013).
Berdasarkan hasil laporan ASI eksklusif dari seluruh Puskesmas Kota Semarang tahun 2010, 2011 dan 2012 masing-masing yaitu 25,10\%, 24,19\% dan $64,01 \%$. Cakupan tersebut masih sangat rendah bila dibandingkan dengan target nasional pencapaian ASI eksklusif tahun 2010 yaitu $80 \%$ (Dinkes kota Semarang, 2012).

Beberapa faktor yang berhubungan dengan praktik menyusui eksklusif, diantaranya adalah kurangnya pengetahuan dan kesadaran ibu akan pentingnya pemberian ASI secara eksklusif, pelayanan kesehatan dan petugas kesehatan yang belum sepenuhnya mendukung program Peningkatan Penggunaan Air Susu Ibu (PP-ASI), gencarnya promosi susu formula, rasa percaya diri ibu yang masih kurang, tingkat pendidikan ibu, dukungan suami dan rendahnya pengetahuan ibu tentang manfaat ASI bagi bayi dan ibu. Dukungan keluarga, terutama suami dapat menentukan keberhasilan atau kegagalan menyusui, sebab dukungan suami akan menimbulkan rasa nyaman pada ibu sehingga akan mempengaruhi produksi ASI serta meningkatkan semangat dan rasa nyaman dalam menyusui (Sartono, 2012).

Di Kota Semarang terdapat 37 Puskesmas. Puskesmas Sekaran merupakan Puskesmas yang mempunyai cakupan ASI Eksklusif paling rendah pada bulan Desember tahun 2012 yaitu sebesar 20, 55\%.

Berdasarkan hal tersebut, maka peneliti tertarik untuk melakukan penelitian tentang "Hubungan pengetahuan dan dukungan keluarga dengan pemberian ASI eksklusif di wilayah kerja Puskesmas Sekaran Kecamatan Gunungpati Kota Semarang”.

\section{METODE PENELITIAN}

Rancangan penelitian yang digunakan dalam penelitian ini adalah retrospektif yaitu penelitian yang berusaha melihat ke belakang (backward looking). Jenis penelitian dalam penelitian ini merupakan penelitian korelasional (hubungan atau asosiasi). Pada penelitian ini populasi diambil semua ibu yang mempunyai bayi usia 7-11 bulan 
sebanyak 47 orang. Sampel sejumlah 47 orang. Metode pengambilan sampel dengan sampel jenuh. Sasaran pada penelitian adalah ibu yang mempunyai bayi berusia 7-11, penelitian dilakukan pada bulan Februari 2014.

\section{HASIL PENELITIAN DAN PEMBAHASAN}

1. Analisis Univariat

a. Pengetahuan tentang ASI Eksklusif

Distribusi responden berdasarkan pengetahuan tentang ASI eksklusif disajikan sebagai berikut:

Tabel 1 Pengetahuan ibu tentang ASI eksklusif di wilayah keja Puskesmas Sekaran Kecamatan Gunungpati Kota semarang

\begin{tabular}{llc}
\hline Tingkat Pengetahuan Ibu & F & $\%$ \\
\hline Kurang & 12 & 25.5 \\
Cukup & 24 & 51.1 \\
Baik & 11 & 23.4 \\
\hline Jumlah & 47 & 100
\end{tabular}

Tabel 1 menunjukkan tingkat Pengetahuan ibu tentang ASI eksklusif, kategori pengetahuan ibu sebagian besar pada kategori cukup yaitu sebesar 24 (51.1\%) responden sedangkan kategori kurang sebesar 12 (25.5\%) responden dan kategori baik $11(23.4 \%)$ responden.

b. Dukungan Keluarga dengan Pemberian ASI Eksklusif

Distribusi responden berdasarkan dukungan keluarga dengan pemberian ASI eksklusif disajikan sebagai berikut:

Tabel 2 Dukungan keluarga dengan pemberian ASI Eksklusif di Wilayah kerja Puskesmas Sekaran Kecamatan Gunungpati Kota Semarang

\begin{tabular}{ccc}
\hline Dukungan Keluarga & F & $\%$ \\
\hline Mendukung & 14 & 29.8 \\
Tidak Mendukung & 33 & 70.2 \\
\hline Jumlah & 47 & 100
\end{tabular}

Tabel 2 menunjukan Dukungan Keluarga dengan pemberian ASI eksklusif, sebagian besar tidak mendukung pemberian ASI eksklusif yaitu sebesar 33 (70.2\%) responden dan mendukung pemberian ASI eksklusif sebesar 14 (29.8\%) responden.

c. Pemberian ASI eksklusif

Distribusi responden berdasarkan pemberian ASI Eksklusif disajikan sebagai berikut:

Tabel 3

Pemberian ASI ekskliusif di Wilayah kerja Puskesmas Sekaran Kecamatan Gunungpati Kota Semarang

\begin{tabular}{lll}
\hline Pemberian ASI eksklusif & F & $\%$ \\
\hline ASI Eksklusif & 4 & 8.5 \\
Tidak ASI Eksklusif & 43 & 91.5 \\
\hline Jumlah & 47 & 100 \\
\hline
\end{tabular}


Tabel 3 menunujukkan Pemberian ASI eksklusif sebagian besaribu tidak memberikan ASI eksklusif yaitu sebesar 43 (91.5\%) respondendan yang memberikan ASI eksklusif sebanyak $4(8.5 \%)$ responden.

\section{Analisis Bivariat}

a. Hubungan pengetahuan tentang ASI eksklusif dengan pemberian ASI eksklusif

Hasil tabulasi silang pengetahuan tentang ASI eksklusif dengan pemberian ASI eksklusif disajikan sebagai berikut:

Berdasarkan hasil analisis uji crosstab pengetahuan dan pemberian
ASI eksklusif diperoleh hasil yang tidak memenuhi syarat untuk dilakukan uji Chi-Square, karena dijumpai 5 cell yang memiliki nilai harapan (expected count) $<5$ lebih dari $20 \%$. Selanjutnya dilakukan uji alternative menggunakan Fisher's Exact Test

Tabel 4

Hasil tabulasi silang pengetahuan tentang ASI eksklusif dengan pemberian ASI eksklusifdi Wilayah kerja Puskesmas Sekaran Kecamatan Gunungpati Kota Semarang

\begin{tabular}{|c|c|c|c|c|c|c|c|}
\hline & & \multicolumn{4}{|c|}{ Pemberian ASI Eksklusif } & \multicolumn{2}{|r|}{ Total } \\
\hline & & \multicolumn{2}{|c|}{ ASI Eksklusif } & \multicolumn{2}{|c|}{$\begin{array}{l}\text { Tidak ASI } \\
\text { Eksklusif }\end{array}$} & & \\
\hline & & $F$ & $\%$ & $F$ & $\%$ & $\mathrm{~F}$ & $\%$ \\
\hline \multirow{3}{*}{$\begin{array}{l}\text { Tingkat } \\
\text { Pengetahuan } \\
\text { Ibu }\end{array}$} & Kurang & 1 & 25 & 11 & 25.6 & 12 & 25.6 \\
\hline & Cukup & 0 & 0 & 24 & 55.8 & 24 & 51.0 \\
\hline & Baik & 3 & 75 & 8 & 18.6 & 11 & 23.4 \\
\hline Total & & 4 & 100 & 43 & 100 & 47 & 100 \\
\hline
\end{tabular}

Tabel 4 menunjukkan bahwa berdasarkan hasil tabulasi silang dan pengujian diatas didapatkan hasil bahwa dari $12(25.6 \%)$ responden yang berpengetahuan kurang terdapat $1(25 \%)$ responden yang memberikan ASI Eksklusif dan $11 \quad(25.6 \%)$ responden yang tidak memberikan ASI eklsklusif sedangkan dari 24 (51.0\%) responden yang berpengetahuan cukup terdapat 24 (55.8\%) responden tidak memberikan ASI eksklusif, dari 11 $(23.4 \%)$ responden yang berpengetahuan baik terdapat 3 (75\%) respondenyang memberikan ASI Eksklusif dan 8 (18.6\%) responden tidak memberikan ASI Eksklusif.
Hasil analisis statistic menggunakan Fisher's Exact Test didapatakan value sebesar 6,221 sehingga $p$ value sebesar $0.016(\mathrm{p}=0.016<0.05)$, sehingga Ho ditolak dan Ha diterima. Hal ini berarti " ada hubungan antara pengetahuan tentang ASI eksklusif dengan pemberian ASI eksklusif di wilayah kerja Puskesmas Sekaran Kecamatan Gunungpati Kota Semarang. 
b. Hubungan Dukungan Keluarga tentang ASI eksklusif dengan pemberian ASI eksklusif

Hasil tabulasi silang Dukungan Keluarga tentang ASI eksklusif dengan pemberian ASI eksklusif disajikan sebagai berikut:

Berdasarkan hasil analisis uji crosstab pengetahuan dan pemberian ASI eksklusif diperoleh hasil yang tidak memenuhi syarat untuk dilakukan uji Chi-Square, karena dijumpai 5 cell yang memiliki nilai harapan (expected count) $<5$ lebih dari $20 \%$. Selanjutnya dilakukan uji alternative menggunakan Fisher's Exact Test.

Tabel 5

Hasil tabulasi silang Dukungan Keluarga tentang pemberian ASI eksklusif dengan pemberian ASI eksklusif di Wilayah kerja Puskesmas Sekaran Kecamatan Gunungpati Kota Semarang

\begin{tabular}{|c|c|c|c|c|c|c|c|}
\hline & & \multicolumn{4}{|c|}{ Pemberian ASI Eksklusif } & \multirow{2}{*}{\multicolumn{2}{|c|}{ Total }} \\
\hline & & \multicolumn{2}{|c|}{ ASI Eksklusif } & \multicolumn{2}{|c|}{$\begin{array}{c}\text { Tidak } \\
\text { ASI Eksklusif }\end{array}$} & & \\
\hline & & $\mathrm{F}$ & $\%$ & $\mathrm{~F}$ & $\%$ & $\mathrm{~F}$ & $\%$ \\
\hline \multirow{2}{*}{$\begin{array}{l}\text { Dukungan } \\
\text { Keluarga }\end{array}$} & Mendukung & 3 & 75 & 11 & 25.6 & 14 & 29.8 \\
\hline & $\begin{array}{l}\text { Tidak } \\
\text { Mendukung }\end{array}$ & 1 & 25 & 32 & 74.4 & 33 & 70.2 \\
\hline Total & & 4 & 100 & 43 & 100 & 47 & 100 \\
\hline
\end{tabular}

Tabel 5 Berdasarkan hasil tabulasi silang dan pengujian diatas didapatkan hasil bahwa dari 14 (29.8\%) responden keluarga yang mendukung pemberian ASI eksklusif, terdapat 3(75\%) responden yang memberikan ASI eksklusif dan $11(25.6 \%)$ responden yang tidak memberikan ASI eksklusif sedangkan dari $33 \quad(70.2 \%)$ responden keluarga yang tidak mendukung pemberian ASI eksklusif terdapat $1(25 \%)$ responden yang memberikan ASI Eksklusif dan 32 (74.4\%) responden yang tidak memberikan ASI Eksklusif.

Berdasarkan hasil uji

Fisher's Exact Testdidapatkan hasil analisis statistic dengan $p$ value sebesar $0.073(\mathrm{p}=0.073>0.05)$, sehingga Ho diterima dan Ha ditolak. Hal ini berarti bahwa " Tidak ada hubungan antara dukungan keluarga dengan pemberian ASI eksklusif di wilayah kerja Puskesmas Sekaran Kecamatan Gunungpati Kota Semarang.

Hasil Penelitian ini akan dibahas secara bertahap dan dari deskriptif sampai analitiknya diantaranya:

1. Pengetahuan Ibu tentang ASI Eksklusif di Wilayah Kerja Puskesmas Sekaran Kecamatan Gunungpati Kota Semarang

Dari hasil penelitian yang telah dilakukan pada 47 responden ibu yang mempunyai bayi 7-11 bulan di wilayah kerja Puskesmas Sekaran Kecamatan Gunungpati Kota Semarang, menunjukkan sebagian besar ibu memiliki pengetahuan cukup yaitu sebesar $24(51.1 \%)$ responden.

\section{Pengetahuan}

merupakan hasil "tahu" dan ini terjadi setelah orang mengadakan penginderaan terhadap suatu 
obyek tertentu. Penginderaan terhadap obyek terjadi melalui panca indera manusia yakni penglihatan,pendengaran,

penciuman, perasa dan peraba dengan sendiri pada waktu penginderaan sampai menghasilkan pengetahuan tersebut sangat dipengaruhi oleh intensitas perhatian persepsi terhadap obyek. Sebagian besar pengetahuan manusia diperoleh melalui mata dan telinga. Hal ini mengingatkan bahwa peningkatan pengetahuan tidak mutlak diperoleh dari pendidikan formal saja, akan tetapi dapat diperoleh melalui pendidikan non formal (Notoatmodjo, 2003).

Berdasarkan hasil penelitian dengan pengetahuan yang kurang sebanyak 12 responden. Hal ini menggambarkan bahwa masih ada sebagian ibu yang memiliki pengetahuan kurang. Pengetahuan ibu tentang ASI eksklusif bisa didapatkan melalui konseling oleh tenaga kesehatan, internet, majalah atau televisi. Tetapi ada beberapa kendala yang mengakibatkan pengetahuan ibu masih kurang yaitu karena kesibukan ibu yang sebagian bekerja selain itu banyak ibu yang menganggap bahwa pengetahuan ASI Eksklusif kurang begitu penting.

2. Dukungan Keluarga tentang pemberian ASI Eksklusif di Wilayah Kerja Puskesmas Sekaran Kecamatan Gunungpati Kota Semarang

Dari hasil penelitian yang dilakukan pada 47 responden menunjukan sebagian besar responden tidak memberikan dukungan pada ibu yaitu sebanyak
$33(70.2 \%)$ responden.Hal ini dikarenakan keluarga banyak beranggapan bahwa apabila bayi menangis menandakan bayi merasa lapar dan harus diberikan makanan tambahan.

Pemberian ASI yang kurang dipengaruhi oleh perilaku dalam memberikan ASI Eksklusif, dimana perilaku seseorang terhadap obyek kesehatan, ada tidaknya dukungan dari keluarga atau masyarakat, informasi yang didapat serta situasi yang memungkinkan ibu mengambil keputusan untuk memberikan MPASI secepatnya atau tidak yang berdampak pada pemberian MPASI (Notoatmodjo, 2003).

3. Pemberian ASI Eksklusif di Wilayah Kerja Puskesmas Sekaran Kecamatan Gunungpati Kota Semarang

Hasil penelitian bahwa responden yang tidak memberikan ASI eksklusif pada bayinya sebanyak $\quad 43 \quad(91.5 \%)$ responden.Hal ini menggambarkan bahwa bayi yang di wilayah kerja Puskesmas Sekaran Kecamatan Gunungpati Kota Semarang sebagian besar tidak mendapatkan ASI eksklusif.

Keberhasilan dalam pemberian ASI eksklusif dapat dilakukan salah satunya dengan cara membantu ibu bagaimana cara menyusui yang benar dan cara mempertahankan menyusui meski ibu dipisah dari bayi,membantu ibu menyusui semau bayi ibu tanpa pembatasan terhadap lama dan frekuensi menyusui (Maryunani, 2012).

Rendahnya pemberian ASI Eksklusif di wilayah kerja Puskesmas Sekaran Kecamatan gunungpati Kota Semarang karena 
responden memiliki pengetahuan yang cukup bahkan kurang.Selain itu disebabkan karena responden bekerja sehingga tidak memiliki waktu untuk memberikan ASI eksklusif kepada bayinya,dukungan keluarga yang diberikan pada ibu kurang,puting susu lecet dan air susu tidak keluar sehingga ibu memberikan susu formula dan makanan padat seperti pisang. Masih banyak juga yang beranggapan bahwa susu formula lebih praktis diberikan saat bayi tidak bersama ibu dari pada harus memompa ASI yang kemudian disimpan dalam kulkas.

4. Hubungan antara Pengetahuan dengan Pemberian ASI Eksklusif di Wilayah Kerja Puskesmas Sekaran Kecamatan Gunungpati Kota Semarang

Hasil penelitian pada tabel menunjukan bahwa responden yang memiliki tingkat pengetahuan tentang ASI eksklusif kurang sebagian besar tidak memberikan ASI eksklusif kepada bayinya yaitu sebanyak 11 (91.7\%) responden dan berpengetahuan cukup sebesar 24 (55.8\%) responden. Pengetahuan yang kurang disebabkan oleh kurangnya informasi yang diterima tentang ASI eksklusif dan sebagian responden beranggapan bahwa pemberian susu formula sudah merupakan pemberian ASI eksklusif, selain itu ketidaktahuan ibu tentang bagaimana cara menyimpan ASI dan memberikan ASI yang sudah diperah. Namun ada pula yang memberikan ASI eksklusif yaitu $1(25 \%)$ responden karena ibu memiliki banyak waktu dirumah dan mendapatkan dukungan dari keluarganya.
Responden yang

memiliki pengetahuan baik tentang ASI eksklusif dan memberikan ASI eksklusif kepada bayinya sebanyak $3(75 \%)$ responden hal ini dikarenakan responden yang telah mengetahui manfaat serta tujuan dari pemberian ASI eksklusif kepada anaknya. Selain itu dengan pengalaman yang dimiliki ibu serta informasi yang diperoleh ibu dari tenaga kesehatan maupun lingkungan kerja memotivasi ibu untuk memberikan ASI eksklusif. Sementara itu responden yang memiliki pengetahuan baik tetapi tidak memberikan ASI eksklusif sebanyak $8 \quad(18,6 \%)$ responden. Hal ini dikarenakan sebagian dari ibu yang memiliki bayi bekerja lebih dari 8 jam serta tidak adanya pojok ASIdan tempat penyimpanan ASI serta dukungan yang diperoleh dari orang terdekat kurang.

Hasil analisis statistic menggunakan Fisher's Exact Test didapatkan value sebesar 6,221 sehingga $\mathrm{p}$ value sebesar $0.016(\mathrm{p}$ $=0.016<0.05$ ), sehingga Ho ditolak dan $\mathrm{Ha}$ diterima. Hal ini berarti "ada hubungan antara pengetahuan tentang ASI eksklusif dengan pemberian ASI eksklusif di wilayah kerja Puskesmas Sekaran Kecamatan Gunungpati Kota Semarang".

Berdasarkan hasil penelitian bahwa responden yang memiliki pengetahuan baik cenderung lebih banyak yang memberikan ASI eksklusif. Hal ini sesuai dengan teori Notoatmodjo (2007) bahwa pengetahuan merupakan hasil tahu dan terjadi setelah orang melakukan penginderaan terhadap suatu 
obyek tertentu. Penginderaan terjadi melalui pancaindera, yakni indera penglihatan, pendengaran, penciuman, perasa, dan peraba. Sebagian besar pengetahuan manusia diperoleh melalui mata dan telinga.

5. Hubungan antara dukungan keluarga dengan pemberian ASI Eksklusif di Wilayah Kerja Puskesmas Sekaran Kecamatan Gunungpati Kota Semarang

Hasil penelitian pada tabel menunjukan bahwa sebesar $14 \quad(29.8 \%)$ responden yang mendukung keluarga terhadap pemberian ASI eksklusif, terdapat $3(75 \%)$ responden memberikan ASI Eksklusif dan $11 \quad(25.6 \%)$ responden tidak memberikan ASI eksklusif sedangkan dari 33 $(70.2 \%)$ responden yang tidak mendukung terhadap pemberian ASI eksklusif, terdapat 1 (25\%) responden memberikan ASI Eksklusif dan $32 \quad(74.4 \%)$ responden tidak memberikan ASI Eksklusif. Bagi sebagian ibu menyusui bukanlah hal yang mudah. Banyak ibu yang kelelahan dan tidak yakin mampu memberikan air susunya untuk bayinya dengan alasan dirinya bekerja.

Berdasarkan hasil uji Fisher's Exact Test didapatkan hasil analisis statistic dengan $\mathrm{p}$ value sebesar $0.073(\mathrm{p}=0.073>$ 0.05), sehingga Ho diterima dan Ha ditolak. Hal ini berarti bahwa " Tidak ada hubungan antara dukungan keluarga dengan pemberian ASI eksklusif di wilayah kerja Puskesmas Sekaran Kecamatan Gunungpati Kota Semarang. Hal ini bertentangan dengan pernyataan berikut "Dengan adanya keluarga yang selalu memberikan dukungan informasi, emosional, instrumental dan penilaian, seorang ibu akan lebih bersemangat dalam memberikan ASI eksklusif kepada bayinya" (Setiadi, 2008).

\section{SIMPULAN}

Dari Hasil penelitian yang dilakukan di wilayah kerja Puskesmas Sekaran Kecamatan Gunungpati Kota Semarang

1. Sebagian besar tingkat pengetahuan ibu tentang ASI eksklusif di wilayah kerja Puskesmas Sekaran Kecamatn Gunungpati Kota Semarang cukup yaitu $24(51.1 \%)$ responden.

2. Sebagian besar Dukungan Keluarga ibu terhadap pemberian ASI ekskusif wilayah kerja Puskesmas Sekaran Kecamatn Gunungpati Kota Semarang Tidak mendukung yaitu 33 (70.2\%) responden.

3. Sebagian besar responden tidak memberikan ASI eksklusif yaitu 43 (91.5\%) responden.

4. Ada hubungan antara pengetahuan tentang ASI eksklusif dengan Pemberian ASI eksklusif di wilayah kerja Puskesmas Sekaran Kecamatan Gunungpati Kota Semarang dengan $\mathrm{p}$ value sebesar 0.016 (p $=0.016<0.05$ ) .

5. Tidak Ada hubungan antara dukungan keluarga ibu tentang ASI eksklusif dengan Pemberian ASI eksklusif di wilayah kerja Puskesmas Sekaran Kecamatan Gunungpati Kota Semarang dengan p value sebesar $0.073(\mathrm{p}=0.073>0.05)$.

\section{DAFTAR PUSTAKA}

Afifah, D. 2007. Faktor yang berperan dalam kegagalan praktik pemberian ASI Eksklusif. Tesis Fakultas Kedokteran Universitas Diponegoro.

Anonim. www. repository.usu.ac.id Diases tanggal 20 Desember 2013

Arikunto. 2010. Prosedur Penelitian Suatu Pendekatan Praktik. Rineka Cipta. Jakarta. 
.2006. Prosedur Penelitian Suatu Pendekatan Praktik. Rineka Cipta. Jakarta.

Depkes. www.depkes.go.id diakses pada tanggal 22 November 2013

Depkes. www.litbang.depkes.go.id diakses pada tanggal 22 November 2013

Dinkes. 2012. Profil Kesehatan Kota Semarang. Depkes RI. Semarang. .2012. Profil Kesehatan Provinsi Jawa Tengah. Depkes RI. Semarang.

Hidayat, A.A. Alimul. 2010. Metode Penelitian Kebidanan dan Teknik Analisis Data. Salemba Medika. Jakarta.

Kristiyansari, Weni. 2009. ASI, Menyusui dan Sadari. Nuha Medika, Yogyakarta.

Malonda, G. 2011.Uji Fisher's exact. (http://statistik-

kesehatan.blogspot.com).

21 Mei 2014

Marmi. 2012. Asi saja mama..berilah aku ASI karena aku bukan anak sapi. Pustaka Pelajar. Jogyakarta.

Maryunani, Anik. 2012. Inisiasi Menyusui Dini, ASI Eksklusif dan Managemen Laktasi. CV. Trans Indo Media, Jakarta.

Notoatmodjo. 2003. Ilmu Kesehatan Masyarakat. Rineka Cipta Jakarta. 2005. Metodologi Penelitian Kesehatan. Rineka Cipta. Jakarta. 2007. Promosi Perilaku Kesehatan. Rineka Cipta.Jakarta. - 2010. Metodologi Penelitian Kesehatan. Rineka Cipta. Jakarta.

Proverawati, E. 2010. Kapita selekta ASI dan menyusui. Nuha Medika.Yogyakarta

Sartono dan Utaminingrum. 2012. Hubungan Pengetahuan Ibu, Pendidikan Ibu dan Dukungan Suami dengan Praktek Pemberian Asi Eksklusif di Kelurahan Muktiharjo Kidul Kecamatan Telogosari Kota Semarang. Jurnal Gizi Universitas Muhammadiyah Semarang, 1:2.
Setiadi. 2008. Konsep dan Proses Keperawatan Keluarga. Graha Ilmu.Yogyakarata.

Wawan, A \& M, Dewi. 2010. Teori dan Pengukuran Pengetahuan, Sikap dan Perilaku Manusia. Nuha Medika, Yogyakarta. 